\title{
THE CREDITORS' RIGHTS TO THE BANKRUPT'S ASSETS
}

Each year for the past several years approximately 125,000 petitions in bankruptcy have been filed under the Federal Bankruptcy Act. ${ }^{1}$ In a proceeding under this act creditors can reach assets of the debtor that are not available to them under state law. ${ }^{2}$ Section 70 a of the act ${ }^{3}$ lists all ${ }^{4}$ the assets of the bankrupt which vest in the bankruptcy trustee ${ }^{5}$ for the benefit of creditors. Difficult problems arise in determining which additional assets can be reached by creditors in bankruptcy under this section.

The numbered clauses of section 70a vest the trustee with the title of the bankrupt, as of the date of the filing of the petition, to: (1) documents relating to title, (2) interests in patents, patent riglits, copyriglits, and trademarks, (3) powers whicl the bankrupt could have exercised for his own benefit, (4) property which he transferred in fraud of his creditors, (6) riglts of action arising upon contracts, usury, and the unlawful taking or detention of or injury to property, (7) future interests in real property which become assignable by the bankrupt withm six months, and (8) property held by an assignee for the benefit of creditors under an assignment which constituted an act of bankruptcy. ${ }^{6}$ The trustee is also entitled to property which vests in the bankrupt within six months of bankruptcy by bequest, devise, or inheritance and property in which the bankrupt had an interest by the entirety at the date of bankruptcy and which becomes assignable within six months of bankruptcy.

Clause (5) of section 70a is the most comprehensive in the section and is broad enough to include most of the property listed in the other clauses. ${ }^{7}$ Under this clause the trustee takes title to all "property, including rights of action, which prior to the filing of the petition he [the bankrupt] could by any means have transferred or which might have been levied upon and sold under judicial process against him, or otherwise seized, impounded, or sequestered."8

130 Stat. 544 (1898), as amended, 11 U.S.C. $\$ \$ 1-112$ (1958); see 1962 DIR. ADMmn. OFF. U.S. Courts, Tabies of Bankruptcy Statistics 6 . This figure does not include the proceedings initiated under Chapters VIII through XIII of the act.

2 See text following note 36 infra.

352 Stat. 879 (1938), 11 U.S.C. $\$ 110$ (1958).

4 See Board of Trade v. Weston, 243. Fed. 332, 335 (7th Cir. 1917).

The statements in English v. Richardson, 80 N.H. 364, 367, 117 Atl. 287, 290 (1922) and In re Baudouine, 96 Fed. 536, 539 (S.D.N.Y. 1899), rev'd on other grounds, 101 Fed. 574 (2d Cir. 1900), to the effect that section 70a is not an exclusive enumeration of the property that vests in the trustee no longer express the correct view. 4 CollIER, Bankruptcy $\{70.07$ n.17 (14th ed. 1962) [hereinafter cited as CoLLIER]. This proposition was also discussed, but not relied on in Chandler v. Nathans, 6 F.2d 725 (3d Cir. 1925). No subsequent case has been found in which a court has allowed property to pass to the trustee without acknowledging that its decision was controlled by the provisions of section 70a.

5 The trustee takes title to the property with right of possession and disposition. However, he is vested with title only for purposes of administering the estate and distributing it among the bankrupt's creditors. See generally 4 CoLIIER II 70.04 .

6 An act of bankruptcy is a legal technicahity that must be satisfied in order to maintain an involuntary petition. MACLACHIAN, BANKRUPTCY 42 (1956).

7 See In re Cantelo Mfg. Co., 185 Fed. 276 (D. Me. 1911). As to whether clause (7) is included within clause (5), see text accompanying notes 65-67 infra.

852 Stat. 880 (1938), 11 U.S.C. $\$ 110$ (1958). The clause continues: "Provided, That rights of action ex dehcto for hibel, slander, injuries to the person of the bankrupt or of a relative, whether or not resulting in death, seduction, and criminal conversation shall not vest in the trustee unless by the law of the State such rights of action are subject to attachment, execution, garnishment, sequestration, or other judicial process ...." Ibid. (Emphasis in 
This Comment will consider which assets of a bankrupt can be reached by his creditors through the provisions of section 70a (5). More particularly it will examine the requirements for satisfying the transferability test of section $70 \mathrm{a}(5)$, treat the problems presented by the inchoate tax refund claims, and discuss the desirability of allowing creditors to reach, through the transferability test, additional assets of the debtor that they could not reach under state law.

\section{I}

\section{DEFINING EXEMPTIONS}

Before discussing the transferability criteria, however, it must be understood that property may be transferable and still not be available to creditors. Section 70 a expressly excepts property "which is lield to be exeinpt" froin passing to the bankruptcy trustee. Some difficulties arise in ascertaining what property "is leeld to be exeinpt." Under section 6 of the act the bankrupt is entitled to any exemptions that he has under either federal or state law. ${ }^{9}$ The federal exemptions are those contained in other federal statutes and relate primarily to federal pensions and soldiers' bonuses. ${ }^{10}$ The state exemptions are far more important and vary considerably from state to state. ${ }^{11}$

State exemptions are also more difficult to identify. It appears that bankruptcy adopts only those exemptions embodied in state statutes, ${ }^{12}$ but the act provides no criteria for distinguishing "exemption" statutes from other state statutes which immunize property froin creditors' claims, and the courts have given little express consideration to developing criteria. ${ }^{13}$ Arguably, the adoption of state "exemption" statutes by section 6 could refer to: (1) all state statutes whicl specify property that is not subject to levy and sale under judicial process, (2) only those state statutes which relate to debtor relief, or (3) only those state debtor relief statutes whose application would be consistent with the unique bankruptcy arrangement.

Bankruptcy courts ${ }^{14}$ have imphicitly rejected the contention that all state statutes which exclude property from levy and sale under judicial process are exemption statutes for bankruptcy purposes. This group of statutes includes more than just debtor relief statutes. Many states, for example, immunize from judicial sale

original.) For a discussion of the relationship between clause (6) and the treatment of rights of action under clause (5) see 70 YaLE L.J. 151 (1960). Clause (5) also has provisions for handling insurance policies with cash surrender values. See generally Riesenfeld, Life Instirance and Creditor' Remedies in the United States, 4 U.C.L.A.L. REv. 583, 614 (1957).

9 "This title shall not affect the allowance to bankrupts of the exemptions which are prescribed by the laws of the Umited States or by the State law in force at the time of the filing of the petition in the State wherein they have had their domicile for the six months immediately preceding the filing of the petition, or for a longer portion of such six months than in any other State." 52 Stat. 847 (1938), 11 U.S.C. § 24 (1958).

10 See 1 Collter $\llbracket 6.17$; MACLACHIAN, BaNkRUPTCY 155 (1956). (1960).

11 Kennedy, Limitation of Exemptions in Bankruptcy, 45 Iowa L. REv. 445, 485-87

12 Smalley v. Laugenour, 196 U.S. 93, 97 (1905); 1 CoLLIER $\llbracket 6.03$.

13 See Comment, 68 YaLe L.J. 1459, 1478-80 (1959).

14 Bankruptcy petitions are filed in federal district courts and the proceedings are administered there. The actual admmistration is conducted by referees, and the matters come before the district jndge only when the referee's rulings are challenged. See generally Cowans, Bankruptcy Law aNd Practice \$\$ 831-39 (1963). 
at least some contingent future interests, ${ }^{15}$ and some states have embodied this rule in statutory form. ${ }^{16}$ Judicial sales of these interests usually result in a return far below their ultimate value. ${ }^{17}$ While some statutes may be directed to preventing sacrifice sales, and hence have a debtor relief purpose, many simply reflect traditional property concepts which fail to regard such insubstantial interests as property. ${ }^{18}$ Bankruptcy courts have ignored the possibility that these statutes could embody bankruptcy exemptions. ${ }^{19}$

If they are not directed toward debtor relief no real problem arises; however, if the statute's purpose is to provide debtor relief, further questions must be answered. In Garber v. Bankers' Mortgage Co. ${ }^{20}$ involving a bankrupt's valuable and freely transferable right of redemption $\mathrm{m}$ otherwise nonexempt real property, the bankruptcy court referred to an earlier holding of the Kansas Supreme Court ${ }^{21}$ that a Kansas statute declaring that "the right of redemption shall not be subject to levy or sale on execution" 22 reflected a general policy of exemption. The bankruptcy court, fully cognizant that it was conclusively bound by the decisions of state courts construing an admitted exemption statute, ${ }^{23}$ realized that the binding effect of a state court determination of what is or is not an exemption statute presented a different problem. As the definition of "property" is not controlled by state decisions, ${ }^{24}$ the court reasoned that state decisions on wliat constitutes an exemption statute also were not binding on the federal courts in bankruptcy proceedings. The court explained that:

The purpose of the exemption statute is to leave a debtor, no matter how hopeless his condition, a place to hve, something to eat and wear, and something to work with. It is not the purpose of an exemption statute to enable a debtor, in addition, to withhold an entirely unlimited amount of valuable property from his honest creditors. Yet, if that section is an exemption statute, that is what it does. 25

The court held that the right of redeinption was not exempt in bankruptcy and that it passed to the trustee. ${ }^{26}$

15 See text accompanying notes 44-47 infra.

16 For example, only vested future interests can be taken on execution to satisfy judgments in Alabama (with regard to realty), Ohio, and Wyoming. Ara. CoDe tit. 7, § 519 (1940); OHIO Rev. Code § 2329.01 (Anderson 1953); Wyo. Star. ANN. § 1-357 (1957).

17 See 2 Powenc, Real Property $\{28 \%$, at 520-21 (1950) [hereinafter cited as Powell]; 4 SIIIES \& SIITH, Future INTEREsTs \$§ 1923-24 (2d ed. 1956) ; Roberts, Assignability of Possibilities of Reverter and Rights of Re-Entry, 22 B.U.L. REv. 43 (1942). While the proposition that future interests do not bring fair value at forced judicial sales is widely assumed, very little factual material exists on it. (1958).

18 Halbach, Creditors Rights in Future Interests, 43 Mins. L. Rev. 217, 217-24, 232-38

10 See Board of Trade v. Johnson, 264 U.S. 1 (1924) (board of trade membership); Young v. Handwork, 179 F.2d 70 (7th Cir. 1949), cert. denied, 339 U.S. 949 (1950) ; Pollack v. Meyer Bros. Drug Co., 233 Fed. 861, 869 (8th Cir. 1916) (concerning opinion) (vested remainder in trust); Fisher v. Cushman, 103 Fed. 860 (1st Cir. 1900) (dictum) (liquor license); Comment, 68 YAIE L.J. 1459, 1478-80 (1959).

2027 F.2d 609 (1928).

21 In re Estate of Wood, 118 Kan. 548, 235 Pac. 864 (1925).

22 Kan. Gen. Star. Ann. \& 60-3455 (1949).

23 Dixon v. Koplar, 102 F.2d 295, 297 (8th Cir. 1939); Arbogast v. Gottried, 58 F.2d 156 (6th Cir. 1932); 1 Colline I 6.03, at 798.

24 The court cited Board of Trade v. Johnson, 264 U.S. 1 (1924) (discussed in text accompanying note 39 infra); Page v. Edmunds, 187 U.S. 596 (1903).

2527 F.2d at $610-11$.

26 Id. at 612. In Jones v. Wakeeney State Bank, 100 F.2d 879 (10th Cir. 1939), the court treated the statute as an exemption statute within the meaning of Section 6 of the Bank- 
Statutes which protect future interests from sacrifice sales and immunize rights of redemption fulfill a valid debtor relief function in the state law context, ${ }^{27}$ but would produce substantially different results if given effect in bankruptcy. Under state law, the statutes provide only a temporary restraint on creditors: when the - future interest vests, it can be levied on, and wlien the right of redemption is exercised or sold, the redeemed property or the proceeds of the sale can be taken to satisfy creditors' claims. Under bankruptcy, the creditors' claims are discharged; ${ }^{28}$ if the property cannot be taken to satisfy the creditors' claims in bankruptcy, it can never be taken. The result of adopting this type of state statute in bankruptcy is not to protect the same property in bankruptcy as is protected under state law; on the contrary, property of the bankrupt eventually available to creditors under state law is pernanently immumized. Section 6 should not be construed to adopt state laws which were not designed to permanently protect a debtor's property from his creditors. ${ }^{29}$

Collier on Bankruptcy has taken the position that Garber is no longer correct in hight of the United States Supreme Court's ruling in Erie R.R. Co. v. Tompkins ${ }^{30}$ "that state decisions inust be followed by the federal court in inatters of general substantive laws." 31 While Erie has imphications beyond the diversity jurisdictional basis in which it arose and may require federal courts to adhere to state decisions interpreting state statutes when substantive rights arise from them, it should not be applicable in this situation. ${ }^{32}$ The rights of a debtor in bankruptcy to the exemptions specified in state statutes do not arise from state law; they arise from the Federal Bankruptcy Act. This act does not have to give bankrupts the exemptions to which they are entitled under state law, and two prior bankruptcy acts did not. ${ }^{33}$ Bankrupts enjoy state exemptions in bankruptcy only because those exemptions are expressly included in the act and only to the extent that they are included. Whether section 6 incorporated into the act all those state statutes which local courts label as exemption statutes or only those statutes which

ruptcy Act, set forth at note 9 supra, relying on state court interpretations. Strangely, neither Garber $v$. Bankers Mort. Co., nor the arguments it raised were mentioned by the court.

27 "Courts have noted three distinct but related purposes served by exemption statutes: (1) protection of individuals and families from pauperism during periods of financial difficulty; (2) encouragement for debtor rehabilitation; and (3) shifting of the burdens of social welfare from the community to creditors." 1 CoLITER 10.03 , at 796-97.

$28 \mathrm{~A}$ bankrupt who complies with the provisions of the act is entitled to a discharge, which he can raise as an affirmative defense to almost all of the debts which were provable in bankruptcy. Tax claims are a significant exception. See generally MacLachlan, BANKRUPTCY 87-115 (1956).

${ }^{29}$ See In re T. C. Burnett \& Co., 201 Fed. 162 (E.D. Tenn. 1912), in which the court, discussing a state statute which immunized a growing crop from levy until it matured, said "It is essential to the exemption of property that it shall be permanently exempt from seizure by creditors in satisfaction of their judgments ...." Id. at 165 .

For a good discussion of the problem which reaches a different conclusion see Countryman, For a New Exemption Policy in Bankruptcy, 14 Rutgers 678, 698 (1960).

30304 U.S. 64 (1938).

31 CorIIER \| 6.03 n.11. This position is supported by In $r e$ Marx, 5 F. Supp. 954 (E.D. Ark. 1933). The court, however, gave no reason for reaching this result. Sec, however, 4 CoIIIER $\llbracket 70.15$, at 1034 n.22.

${ }^{32}$ Cf. Mishkin, The Variousness of "Federal Law": Competence and Discretion in the Choice of National and State Rules for Decision, 105 U. PA. L. REv. 797 (1957).

33 Bankruptcy Act of 1800, ch. 19, §§ 5, 18, 34, 53, 2 Stat. 23, 26, 30, 34; Bankruptcy Act of 1841, ch. 9, §3, 5 Stat. $442-43$. 
are designed to permanently protect a debtor's property is a matter of statutory interpretation. The final interpretation of federal statutes is a matter exclusively within the province of the federal courts. ${ }^{34}$

\section{II}

\section{THE TRANSFERABILITX TEST}

In order for assets of the bankrupt to pass to the trustee, they must not only be nonexempt but must also come within the provisions of section 70a. Clause (5) of this section establishes two alteruative standards for determining whether the trustee will take title: (1) could the bankrupt, by any means, have transferred the property prior to the filing of the petition, or (2) could the property have been subjected to levy and sale under judicial process. If either of the tests are met, the property passes by operation of law ${ }^{35}$ to the bankruptcy trustee as of the date the bankruptcy petition was filed. ${ }^{36}$ Outside of bankruptcy only property which can be levied upon and sold under judicial process "or otherwise seized, impounded or sequestered" is subject to creditors' claims. The significance of the transferability test in the bankruptcy proceeding is that it subjects additional assets of the bankrupt to the claims of creditors.

Clause (5) expresses the transferability test in the terms "property ... which .. . he could by any means have transferred." In applying this test, bankruptcy courts will look to state law to see if the asset is transferable, ${ }^{37}$ except when the asset is governed by a special federal statute. ${ }^{38}$ The refusal, however, of state law to affix the label of "property" to a transferable asset will not preclude it from passing to the trustee. In the leading case of Board of Trade v. Johnson ${ }^{39}$ the United States Supreme Court indicated that the crucial determinant of whether an asset passes to the trustee is whether it is transferable, not whether it is called "property." 10

All interests which are transferable at law ${ }^{41}$ can pass to the trustee under the

34 See Textile Workers Union v. Lincoln Mills, 353 U.S. 448 (1957) ; D'Oench, Duhme \& Co. v. Federal Deposit Ins. Corp., 315 U.S. 447 (1942); Mishkin, supra note 32.

35 The transfer is automatic and the bankrupt's cooperation is not usually necessary. 4 COLIIER 7 70.04, at 948 .

30 Page v. Edmunds, 187 U.S. 596, 601 (1903) ; Patrick v. Beatty, 202 N.C. 454, 460, 163 S.E. 572, 575 (1932). See Fisher v. Cushman, 103 Fed. 860, 866 (1st Cir. 1900). If the property is covered by the express exception in clause (5), quoted in note 8 supra, it does not pass to the trustee although one or both of the tests are satisfied.

37 In re Berry, 247 Fed. 700 (E.D. Mich. 1917); 4 ColzIER If 70.15, at 1034; Cowan, BaNkRUPTCY LAW AND PRACTICE \$ 553, at 298 (1963); MACLACHLAN, BANKRUPTCY 170 (1956). See, e.g., Horton v. Moore, 110 F.2d 189, 191 (6th Cir.), cert. denied, 311 U.S. 692 (1940); Thummess v. Von Hoffman, 109 F.2d 293, 295 (3d Cir. 1940); In re Ford-Rennie Leather Co., 2 F.2d 750, 754 (D. Del. 1924).

38 See cases cited in 4 ColrIER $\| 70.15$ n.22.

39264 U.S. 1 (1924).

40 Intangible, transferable assets, like stock exchange seats and liquor licenses are "property" within the meaning of the act and pass to the trustee. Page v. Edmunds, 187 U.S. 596 (1903) ; Board of Trade v. Weston, 243 Fed. 332 (7th Cir. 1917); Fisher v. Cushman, 103 Fed. 860 (1st Cir. 1900) ; 4 CoLIIER 870.22 , at 1171-76. It would seem that any transferable asset, at least if it has value, constitutes "property" within the meaning of section 70a (5). See In re Quaker Room, 90 F. Supp. 758, 761 (S.D. Cal. 1950).

There are, however, limitations on the powers of a bankruptcy court to override state law. For instance, questions of title to property are ordinarily decided by state law. See Thompson v. Magnoha Petrol. Co., 309 U.S. 478 (1940). See generally Hill, The Erie Doctrine in Bankruptcy, 66 HARV. L. REV. 1013 (1953).

41 See definition of free transferability in text accompanying note 48 infra. 
transferability test. ${ }^{42}$ There is a controversy, however, whether interests transferable only in equity can pass to the trustee. Most of the difficulty has arisen when the bankrupt owned a future interest ${ }^{43}$ prior to filing the petition. There is a lack of uniformity among the states in treating future interests. Reversions and vested remainders are freely transferable in all states. ${ }^{44}$ Possibilities of reverter are freely transferable in most states. ${ }^{45}$ Contingent reinainders and executory devises are freely transferable in most jurisdictions, but at least eleven states distinguish between remainders contingent "as to event" and "as to person," holding that the latter are not freely transferable.6 Rights of entry for condition broken are generally not freely transferable, although there are some exceptions. ${ }^{47}$ Freely transferable means "transferable without consideration by quitclaim deed to a stranger to the title." 48

While a future interest may not be freely transferable by this criterion, there are generally recognized exceptions to the inalienability of property. One who purports to convey, for consideration, a subsequently-to-be-acquired interest in property will find the conveyance treated as a contract to convey which will be specifically enforced in favor of the promisee after the promisor acquires the interest. ${ }^{40}$ This is known as an assignment in equity. Another principle which results in the transfer of an inalienable future interest is estoppel by deed. One who purports to convey by warranty deed an interest he is not presently capable of conveying will find himself estopped to deny his prior lack of ownership if he later acquires the interest. ${ }^{50}$ Finally, through the release doctrine, the policy opposing the indirect suspension of alienation has resulted in permitting a valid transfer of an otherwise inalienable future interest to the holder of another interest in the property. $^{.1}$

Dispute has arisen over whether these more restricted forms of transfer are included within the phrase "by any ineans," or whether the phrase is limited to the definition of free transferability. The Seventh Circuit has adopted the position that "by any means" also includes transfers enforceable only in equity. In In re Landis, ${ }^{52}$ the Court of Appeals for the Seventh Circuit ${ }^{53}$ found it unnecessary to

42 See generally 4 CoLrues $\llbracket 70.15$.

43 "A future interest may be described as an interest in land or other things in which the privilege of possession or of enjoyment is future and not present. It should be emphasized that the interest is an existing interest from the time of its creation, and is looked upon as a part of the total ownership of the land or other thing which is its subject matter." 1 Smes \& SMITH, FUTURE INTERESTS \& 1, at 2-3 (1956).

442 Powell If 281, at 481; đI 283, at 492-93 (1950).

45 Id. $\llbracket 281$.

46 Halbach, supra note 18, at 222.

472 POWELT $\llbracket 282$.

48 Halbach, supra note 18, at 224.

49 Ibid.

Professor Powell suggests that "this device is probably not helpful as to future interests in personalty because of the general imapplicability of specific performance to contracts affecting personalty:" 2 Powsic \283, at 495. Professor Corbin, however, makes no distinction. "A present assignment of rights under a contract or employment that does not exist, may, as between the assignor and the assignee, be regarded as a binding contract to assign in the future when the operative facts creating the right shall have occurred." 4 CoRBIN, ConTracrs $\$ 874$, at $507-08$ (1951).

502 Powerc If 283, at 495-96.

51 Halbach, supra note 18 , at 224

5241 F.2d 700 (7th Cir. 1930).

53 Judge Page concurred in the result as he was of the opinion that the bankrupt had a vested interest, but he did not agree that a contingent interest passes to the trustee. $I d$. at 703 . 
resolve whether the bankrupt's interest in real estate was a vested remainder freely transferable under Inlinois law or a contingent remainder which clearly was not transferable. The court noted that a contingent remainder was assignable in equity and declared that this was sufficient to pass the bankrupt's interest to the trustee. ${ }^{54}$

In re Landis has been severely criticized. Professor Powell ${ }^{55}$ argues that to vest in the trustee future interests which are not freely transferable and thus not subject to the claims of creditors under state law, ${ }^{56}$ places a premium on involuntary bankruptcy. The Restatement of Property reflects this reasoning: "The uniformity which keeps identical the future interests subject to creditors' process under state laws and under the Bankruptcy Act, is more important than a uniformity of rule throughout the whole United States as to bankruptcies." 57

This contention overlooks the effect of the discharge ${ }^{58}$ in bankruptcy. While creditors may not be able to levy on contingent interests in some states, if they have patience they can wait until the interest vests and then levy on the vested interest to satisfy their claims. If, however, the debtor can obtain a discharge in bankruptcy without having his future interest included in the administrable assets, he will find bankruptcy advantageous. Thus, the premium is on voluntary bankruptcy.

The argument of the Restatement also fails to fully appreciate that subjecting additional assets of the bankrupt to the claims of creditors in excess of what could be reached under state law is the result of the deliberate congressional choice of the dual tests of leviability or transferability ${ }^{59}$ Complete uniformity between state law and the Bankruptcy Act would be achieved by using only the leviability test. The inclusion of the transferability test, however, which covers property not included in the leviability test, precludes uniformity. ${ }^{60}$ While it may be argued that the result under the Bankruptcy Act and state law should be the same, under the language of section 70a (5) legitimate criticisin cannot be leveled at In re Landis for achieving a contrary result. ${ }^{61}$ It is clear, however, that the Landis decision is in the minority. No cases have been found in the other circuits supporting it $^{62}$ and at least five circuits have refused to allow future interests that are not freely transferable to pass to the trustee. ${ }^{63}$

54 The court cited In re Moore, 22 F.2d 432 (D. Md. 1927), where a contingent remainder, assignable only in equity under Maryland law, was allowed to pass to the trustee. However, in a subsequent case, Suskin \& Berry, Inc. v. Rumley, 37 F.2d 304 (4th Cir. 1930), the court refused to allow a contingent remainder to pass to the trustee on the ground that it was not assignable under Maryland law. In re Moore was not mentioned.

552 Power. \I 287.

56 If a future interest is not freely alienable, this fact will preclude creditors from reaching it under state law. Halbach, supra note 18 , at 226.

57 Restatendent, Property $\$ 168$, comment $e$, at $641-42$ (1936).

58 See note 28 supra.

59 See 4 CoLrifer II 70.37 n.6.

60 See text following note 36 supra.

61 In re Landis was decided under section 70a (5) in 1930. Clause (7), discussed in text accompanying notes 65-67 infra, was added to section $70 \mathrm{a}$ in 1938 .

62 See discussion of In re Moore at note 54 supra.

63 In re Martin, 47 F.2d 498 (6th Cir. 1931); Suskin \& Berry v. Rumley, 37 F.2d 304 (4th Cir. 1930); In re Wetmore, 108 Fed. 520 (3d Cir. 1901); In re Ehle, 109 Fed. 625 (D. Vt. 1901); Hasseltine v. Prince, 95 Fed. 802 (D. Mass. 1899) (tenancy by the courtesy initiate). 
The result of these decisions was thought to allow debtors to use the discharge in bankruptcy to defeat their creditors. "Liberal credits are frequently extended by tradesmen in reliance upon such interests and quite often such debtors invoke the [Bankruptcy] Act in time to escape payment." 64 To prevent this result, at least to a limited degree, Congress in 1938 inserted clause (7) into section 70a, vesting the trustee with title to

\begin{abstract}
contingent remainders, executory devises and limitations, rights of entry for condition broken, rights or possibilities of reverter, and like interests in real properly, which were nonassignable prior to bankruptcy and which, within six months thereafter, become assignable interests or estates or give rise to powers in the hankrupt to acquire assignable interests or estates. 65
\end{abstract}

While the immediate result of this clause was to insure that creditors would receive some of the future interests which the majority of the circuits had denied them, it also may preclude the courts from holding that assignability in equity is sufficient to satisfy transfer "by any means." Clause (7) would be meaningless unless there were some future interests that were nonassignable within the meaning of clause (5). As all future interests are assignable in equity, ${ }^{60}$ such assignments of future interests in realty must be insufficient to satisfy the requirements of transfer "by any means." The effect of the amendment is even broader. There is no basis within clause (5) to distinguish future interests in realty from other interests in property. As free transferability is required for future interests in real property to pass to the trustee, it would seem it must also be satisfied before other property interests can pass. It is not at all clear that this result was intended, ${ }^{67}$ but if clause ( 7 ) is to have any meaning, transfer "by any means" must exclude interests assignable only in equity and require free transferability for a property interest to pass to the trustee.

The requirement of free transferability does not result in complete uniformity between state law and bankruptcy, but it greatly narrows possible differences by making the subjection of a future interest in bankruptcy conform to state property laws.

\title{
III
}

\section{INCHOATE CLAIMS FOR TAX REFUNDS}

The difficult problem of interpreting and applying section $70 \mathrm{a}$ that arises when the bankrupt is the owner of an inchoate interest at the time of the filing of the petition is well illustrated by recent cases involving the bankrupt's right to a federal income tax refund.

Under section 70a the trustee is vested only "with the title of the bankrupt as of the date of the filing of the petition." 68 To pass to the trustee, the assets of the

64 H.R. Rep. No. 8046, 75th Cong., 3d Sess. 34 (1937).

65 52 Stat. 880 (1938), 11 U.S.C. $\$ 110$ (1958). (Emphasis added.)

662 PoweLL § 283 ; Halbach, supra note 18, at 224-25.

67 See MacLachlan, "By Any Means," 67 CoM. L.J. 193 (1962).

68 Bankruptcy Act $\$ 70 a, 52$ Stat. 879 (1938), 11 U.S.C. $\$ 110$ (1958). This must be qualified by the express exceptions in the section discussed at note 8 supra. 
bankrupt must have been transferable property prior to the filing of the petition. ${ }^{69}$ It is well established that the trustee succeeds to a bankrupt's claims for refunds that were determinable and enforceable by the bankrupt prior to the filing of the petition. ${ }^{70}$ The courts have found ${ }^{71}$ these claims to be covered by the language of section $70 \mathrm{a}(6)^{72}$ which refers to rights of action arising from the unlawful detention of property. The problem occurs when the right to a tax refund arises out of the bankrupt's economic activity during the year in which the petition is filed.

This question was first discussed by the Court of Appeals for the Third Circuit in In re Sussman. ${ }^{73}$ The taxpayer filed a petition in bankruptcy in June after suffering heavy financial losses during the early part of the year. The same losses which caused the bankruptcy also produced a substantial net operating loss for the taxable year, entitling the bankrupt to a tax refund ${ }^{74}$ as a result of the loss carry-back adjustment provided by Internal Revenue Code (1954) Section 172.75 The court observed that the net operating loss upon which any carry-back claim is based is the excess of allowable deductions over the taxpayer's gross income for a taxable year. "Thus, the statutory scheme precludes the existence of any carry-back claim until the end of a taxable year."76 As the claim does not arise until the end of the taxable year, at the time the bankruptcy petition was filed the bankrupt could have no cause of action against the government.

The court concluded that the likelihood in June of the taxpayer being able to assert a loss carry-back refund claim at the end of the year did not amount to property. Property, said the court, connotes "an interest in some res, whether that res shall be corporeal property or a chose in action," and prior to the time the petition was filed, the bankrupt "could point to no existing fund and to no existing cause of action in which he had any legal or equitable interest." 77 Fimally, the court indicated that even if the bankrupt's expectation of the refund could be

60 Ibid.

70 Chandler v. Nathans, 6 F.2d 725 (3d Cir. 1925) ; 4 CourIer $\llbracket 70.28$, at 1250.

71 E.g., Chandler v. Nathans, supra note 70, at 728.

72 Bankruptcy Act $\S 70$ a (6), 52 Stat. 880 (1938), 11 U.S.C. $\$ 110$ (1958).

73289 F.2d 76 (3d Cir. 1961).

74 The bankrupt's tax refund arose as a result of applying the carry-back adjustment to offset the bankrupt's taxable income of the two preceding years. For those years, the bankrupt had filed a joint income tax return with his wife. While the lower court, 188 F. Supp. 320 (E.D. Penn. 1960), did not rely on this fact in denying the trustee any interest in the refund claim, it quoted from the referee's opinion: "When the tax was paid by the husband and wife, that part of the husband's money that was used to pay the tax was held by them by entireties and [the] chose in action which arose against the government by reason of the carryback provisions of the Internal Revenue Code was consequently held by them as tenants by entireties." " 188 F. Supp. at 323 . The court pointed out that if the bankrupt's property is an interest by the entirety, the trustee gets nothing unless all or part of the property becomes transferable by the bankrupt within six months after the petition is filed. Id. at 322 . This consideration was not discussed by the court of appeals.

75 Int. REv. CODE OF $1954 \$ 172$ allows the businessman for tax purposes to average the extreme ups and downs of business income over a period of years. Subject to certain modifications provided in the section, the net operating loss, the excess of deductions over gross income of the current year, can be carried back to offset the income of the three preceding years and, to the extent that it exceeds the income of these years, it can be carried forward for five years as a deduction against taxable income for those years. When it is carried back to offset the income of a previous year, the tax on which is paid, the result is a refund. See STANLEy \& KIICULIEN, FEDERAL INCOAre TAX, 97-99 (4 ed. 1961).

76289 F.2d at 77.

77 Id. at 78 . 
described as a contingent claim, the Assignment of Claims Act $^{78}$ would render it nontransferable. The result was that the refund check went to the bankrupt as after acquired property and thereby immune, through the bankrupt's discharge, from the claims of his creditors.

The court realized that this outcome was unsatisfactory. The same financial losses which destroy the bankrupt's ability to pay his creditors give rise to the loss carry-back claim. It is particularly unfair that the creditors should be deprived of this asset in satisfying their claims. However, despite the "inequitable consequences," the court thought that the statute required the result. ${ }^{\mathbf{7 0}}$

The Sussman result has been vigorously criticized, ${ }^{80}$ and was rejected by the Northern District of Texas in In re Segal, in which the court held that the title to the loss carry-back vested in the trustee. ${ }^{81}$ The court correctly noted that in light of the decisions of the United States Supreme Court in Enwin v. United States $^{82}$ and National Bank of Commerce v. Downic, ${ }^{83}$ the Assignment of Claims $\mathrm{Act}^{84}$ does not apply to transfers by operation of law and should not be a barrier to the carry-back claim passing to the trustee. ${ }^{85}$ Its other argnments, however, do not meet the objections that must be overcome before the loss carry-back refund can vest in the trustee under section 70a. The court took the position that the inability of the bankrupt to present his claim prior to the filing of the petition did not prevent him from having an existing property right at that time, analogizing it to the property interest that one who holds a note payable at the end of the year has before the due date. Nor did the court think that the uncertainty of the claim, based on the possibility that subsequent earnings during the year might destroy the likely net operating loss, would prevent it from passing to the trustee. The court cited Williams v. Heard, ${ }^{86}$ in which the United States Supreme Court allowed the bankrupt's claim for losses, indirectly caused by British-built Confederate cruisers, to pass to the trustee although it was unlikely that the claim would ever be enforceable, to show that claims of even greater uncertainty vest in the trustee.

78 "All transfers and assignments made of any claim upon the United States, or of any part or share thereof, or interest therein, whether absolute or conditional, and whatever may be the consideration therefor, and all powers of attorney, orders, or other authorities for receiving payment of any such claim, or of any part or share thereof, shall be absolutely null and void, unless they are freely made and executed in the presence of at least two attesting witnesses, after the allowance of such a claim, the ascertainment of the amount due, and the issuing of a warrant for the payment thereof ..." 10 Stat. 170 (1853), 31 U.S.C. \& 203 (1958).

79 The same result was reached in Fournier v. Rosenblum, 318 F.2d 525 (1st Cir. 1963).

8014 Stan. L. Rev. 380 (1962) ; 16 U. Mrami L. Rev. 345 (1961).

81221 F. Supp. 282 (N.D. Tex. 1963).

8297 U.S. 392 (1878). The Court allowed a claim against the federal government for goods seized by military authorities to pass to the trustee. The Court explained that the Assignment of Claims Act "does not embrace cases where there has been a transfer of title by operation of law. The passing of claims to assignees in bankruptcy is not within the evil at which the statute is aimed ... IId. at 397. See generally Note, Unassignable Claims Against the United States: A Commercial Anachronism, 68 YAIE L.J. 515 (1959).

83218 U.S. 345 (1910). The language of Erwin v. United States, supra note 82, was repeated by the court in Downie, which permitted unallowed contract claims against the federal government to pass to the trustee.

84 See note 78 supra.

854 CoLLIER $\| 70.28$, at $1250-55$.

86140 U.S. 529 (1891). At the time of bankruptcy, the commission administering the indemnity fund was authorized to receive only claims for damage that directly resulted from the activities of the Confederate vessels, and it was unlikely that the bankrupt's claim for indirect damage would ever be enforceable. 
These arguments overlook a critical distinction. In the case of a note payable at the end of the year there is no doubt during the year that the holder will have a right to collect at the due date. In Williams v. Heard the Court made clear that, although there was doubt as to whether the bankrupt's claim would ever be collectible, it was a valid existing claim at the time of the assignment to the bankruptcy trustee. ${ }^{87}$ The problem presented by the inchoate loss carry-back is not that the claim for a refund cannot be presented at the time the petition is filed or that there is no certainty at the time the petition is filed that the claim will be collectible. The problem is that there is no certainty at the time the petition is filed that the bankrupt will ever have a valid claim, and hence, at that time, the bankrupt has nothing which he can transfer within the meaning of section $70 \mathrm{a}(5)$.

The court in Segal also concluded that under the test adopted by the Court in Heard-if the interest would pass to an administrator in case of intestacy, it is capable of passing to the trustee in bankruptcy-the bankrupt in Sussman had an existing property right. This test, however, was suggested ${ }^{88}$ for an earlier bankruptcy act which used substantially different terms than those used in section $70 \mathrm{a}$ of the current act, ${ }^{89}$ and cannot validly be applied to the inchoate loss carry-back claim. There would be no problem if the bankrupt were dead since the taxable year ends upon death; ${ }^{00}$ the difficulty exists because at the time the petition was filed the taxable year was not over and it was possible that subsequent income would erase the net operating loss and preclude the bankrupt from ever having a refund claim.

At the time the bankruptcy petition was filed, the bankrupt had no interest in any res; all he had was the likelihood that at the end of the taxable year he would be entitled to a refund, a fine idea, but not a transferable interest in property. It has been suggested that such an interest could be transferred in equity and thereby vest in the trustee. ${ }^{91}$ As previously indicated, however, the 1938 amendment to section 70a appears to exclude assignments in equity from satisfying the transferability test. ${ }^{92}$

The Sussman court was correct in holding that the inchoate loss carry-back claim did not vest in the trustee, but while the outcome of the case is correct under the present statutory language, the result, as the court indicated, is not satisfactory..$^{\text {ss }}$

\footnotetext{
87 Williams v. Heard, stepra note 86 , at 541 .

88 Comegys v. Vasse, 26 U.S. (1 Pet.) 193 (1828). The case arose under Bankruptcy Act of 1800 , ch. $19, \S 5,2$ Stat. 19.

8952 Stat. 880 (1938), 11 U.S.C. $\$ 110$ (1958). Section 5 of Bankruptcy Act of 1800, ch. 19, $\S 5,2$ Stat. 19, allowed the creditors "all the [nonexempt] estate, real and personal, of every nature and description to which said bankrupt may be entitled . . . in any manner whatsoever...."

90 Int. Rev. Code of 1954 \$ 443 (a) (2).

0114 Stan. L. REv. 380, 385 (1962).

92 See text accompanying notes 65-67 supra.

03 It can be assumed that the problem presented in Sussman is not uncommon. If a bankrupt has had a sufficiently profitable year to pay income taxes in any of the three years preceding bankruptcy, and in the year of bankruptcy has a net operating loss within the meaning of INT. REv. CODE of $1954 \S 172$, he is entitled to a carryback adjustment refund. Under the present law, the timing of the bankruptcy petition is crucial in determining whether the bankrupt or the trustee receives the refund. If the petition is filed the day after the end of the taxable year in which the net operating loss is sustained, the claim passes to the trustee, but if a
} 


\section{CONCLUSION}

.The transferability test produces unsatisfactory results when used to determine whether the bankrupt's inchoate claims to tax refunds and ownership of future interests are to be subjected to creditors' claims in bankruptcy.

Although the language of section $70 \mathrm{a}$ (5) is not broad enough to include the mchoate right to a tax refund claim, this result is undesirable. Creditors should receive the refund which arises from the very losses which render the bankrupt incapable of paying his debts. The Act should be amended to entitle the trustee to property, including rights of action, which vest in the bankrupt within a year of the filing of the petition, to the extent that such property is attributable to the activity of the bankrupt or to his economic experience prior to filing the petition. ${ }^{94}$

The treatment of the bankrupt's future interests presents a more difficult problem. When the trustee hquidates the assets of a bankrupt, contingent future interests are often sold to speculators for a fraction of their possible worth. ${ }^{95}$ The creditor receives very hittle to satisfy his claims, and the debtor is deprived of an asset that may become very valuable. The creditor gains little in comparison with what the debtor may lose.

On the other hand, if a future interest is not included in the bankruptcy estate, the interest may vest soon after the petition is filed, leaving the bankrupt in possession of a valuable asset, which is immune from the claims of his creditors, although his debts may be completely unsatisfied.

Clause (7) attempts to solve this problem; but even within its limited scope,

taxpayer foresees the eventual bankruptcy, he can save the refund check for himself by filing his bankruptcy petition before the taxable year ends.

A parallel problem is presented by In re Goodson, 208 F. Supp. 837 (S.D. Cal. 1962). At the beginning of the taxable year, the bankrupt had understated his exemptions for the withholding of federal income tax from his salary, so at the time of bankruptcy, there was the likelihood of a refund at the end of the taxable year. The court took the position that the portion of his wages withheld constituted a particular fund, and that the possibility that the bankrupt would regain some of his money from the fund constituted his personal property. After indicating that the interpretation of section 70a should be broad in order to effectuate the purpose of the Bankruptcy Act, the court discussed the general policy of Californin law favoring the free alienability of all types of property. The court cited Cahfornia cases to show that analogous interests were assignable in equity. The result of the court's reasoning was to vest the trustee with title to that portion of the refund which was attributable to wages earned prior to bankruptcy.

The court's assertion that there was a fund in which the bankrupt could have an interest is highly questionable. Equally questionable is the use of state law to determine whether a federal claim is transferable within the meaning of the Bankruptcy Act. See note 38 stipra. An even greater obstacle to the result of the court is the use of assignability in equity as a test to determine whether property passes to the trustee. See text accompanying notes 65-67 supra.

See also In re Gignac, 222 F. Supp. 557 (N.D.N.Y. 1963).

94 The National Bankruptcy Conference is considering proposiug an amendment to the act. As the proposed amendinent now reads, section $70 \mathrm{a}(6)$ would be amended to read: "rights of action arising upon contract . . or statute, including rights accriting after bankruptcy on account of payments made, consideration given, or services rendered before bankruptcy, and rights of action for the (unlawful) taking or detention of or injury, to his property." Letter from Leon S. Forman to Professor William T. Laube, December 2, 1963. Some of the language, i.e., "accruing after bankruptcy" is considered ambiguous, and the amendment is still under consideration by the Conference.

95 See note 17 supra. 
its operation is not satisfactory as it merely allows contingent future interests in realty which become transferable within six months after the petition is filed to pass to the trustee. It is submitted that the transferability criteria is not a satisfactory standard when apphed to contingent future interests. The considerations determining that a property interest shall be freely transferable and those dictating that it shall be liable for creditors' claims are not necessarily the same. The fact that an interest is not freely transferable may reflect the policy of state law that such an interest should not be subject to creditors' claims, but the existence in some states of freely transferable future interests that cannot be reached by state judicial process demonstrates that this policy does not always determine whether future interests sliall be freely transferable. It is not inconsistent to protect a contingent interest from forced sale to speculators and at the same time to allow the holder to transfer it freely if profitable.

There should be a uniform rule, however, determining whether contingent future interests will pass to the trustee and this rule should be based on two considerations: (1) the disproportionate loss to the bankrupt from a sacrifice sale and (2) the possible loss to creditors when the bankrupt's contingent remainder vests shortly after the petition is filed, giving him a valuable property right. These considerations are not reflected by the application of the transferability test to future interests. A possible solution might be to amend section 70a (7) of the act so that the trustee would be entitled to all contingent future interests, rather than just those in realty, which the bankrupt had prior to the filing of the petition and which vest in the bankrupt within a given period after bankruptcy. It is suggested that this period be substantially longer than the present six month limitation in clause (7). This would meet the objections presented by both evils of sacrifice sales and situations in which the debtor uses bankruptcy to immunize his contingent interest from creditors' claims. ${ }^{96}$

Patrick L. Shreve

80 See Halbach, supra note 18, at 246-50. 